\title{
A Retrospective Study in 5,989 Patients with Type 1 Diabetes in 10 Outpatient Diabetes Clinics in Sweden of the Frequency of Measuring HbA1c in Clinical Practice
}

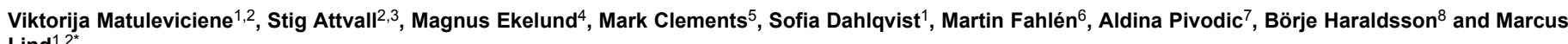
Lind $^{1,2^{*}}$

${ }^{1}$ Department of Medicine, NU-Hospital Organization, Sweden

${ }^{2}$ Department of Molecular and Clinical Medicine, University of Gothenburg, Sweden

${ }^{3}$ Department of Medicine, Sahlgrenska University Hospital, Sweden

${ }^{4}$ Department of Medicine, Helsingborg Hospital, Helsingborg, Sweden

${ }^{5}$ Children's Mercy Hospital, Kansas City, USA

${ }^{6}$ Department of Medicine, Kungälvs Hospital, Kungälv, Sweden

${ }^{7}$ Statistiska Konsult gruppen, Gothenburg, Sweden

8 Institute of Medicine, University of Gothenburg, Gothenburg, Sweden

"Corresponding author: Marcus Lind, Department of Medicine NU-Hospital Organization and Department of Molecular and Clinical medicine, University of Gothenburg, Gothenburg, 45180 Uddevalla, Sweden, Tel: +46 (0) 1043500 00; Fax: +46 (0) 1043571 66; E-mail: lind.marcus@telia.com

Rec date: Apr 26, 2014, Acc date: May 26, 2014, Pub date: May 29, 2014

Copyright: (c) 2014 Matuleviciene V, et al. This is an open-access article distributed under the terms of the Creative Commons Attribution License, which permits unrestricted use, distribution, and reproduction in any medium, provided the original author and source are credited.

\begin{abstract}
Aim: Guidelines for the treatment of type 1 diabetes generally recommend quarterly or more frequent Haemoglobin A1c (HbA1c) assessment in patients with inadequate glycaemic control. The purpose of the current study was to evaluate to what extent these guidelines are followed in clinical practice in Sweden.

Method: We studied 5989 patients with type 1 diabetes from 10 outpatient diabetes clinics in Sweden from 1 January 2005 to 31 December 2009. Data on HbA1c measurement frequency were obtained from the Diab-Base electronic medical records database, where $\mathrm{HbA} 1 \mathrm{c}$ measurements are recorded together with other patient characteristics, including treatment and other general risk factors for diabetic complications. The frequency of $\mathrm{HbA} 1 \mathrm{c}$ measurements was obtained for all patients by calendar year, care unit, and during time periods where glucose was classified as well controlled (HbA1c $<=7.0 \%$ ) or inadequate (HbA1c $7.0 \%$ or higher).
\end{abstract}

Results: The mean annual number of $\mathrm{HbA} 1 \mathrm{c}$ assessments when glucose control was inadequate was 1.83 compared with 1.58 during well controlled time-periods. In $35.4 \%$ of cases the next $\mathrm{HbA} 1 \mathrm{c}$ check following an $\mathrm{HbA} 1 \mathrm{c}$ $>7 \%$ was performed within 4 months. The probability of a subsequent assessment in the 4 months following an $\mathrm{HbA} 1 \mathrm{c}$ value $>7.0 \%$ increase in patients treated with continuous subcutaneous insulin infusion (CSII), OR=1.57 (1.46-1.69). Differences were also noted by care unit, age, gender, glycaemic control, calendar year, and weight and diabetes duration.

Conclusion: In patients with type 1 diabetes, $\mathrm{HbA} 1 \mathrm{c}$ is measured less frequently in clinical practice in Sweden than guidelines recommend, although patients with CSII and treated in certain care units receive more frequent assessments.

Keywords: Type 1 diabetes mellitus; HbA1c; Diabetic complications; Insulin pump; Availability; Diabetes care

\section{Background}

Diabetes mellitus remains a growing public health problem. There are approximately 385 million people worldwide with diabetes (types 1 and 2), and the prevalence is predicted to rise to 500 million by 2030 [1]. The prevalence of type 1 diabetes mellitus is highest in Scandinavian countries and has increased in several countries during the last decades [2-4]. The costs associated with diabetes account for more than $10 \%$ of the entire European health budget, with diabetes complications accounting for a major part of these costs $[5,6]$.
Good glycaemic control is crucial in preventing complications in patients with type 1 diabetes $[7,8]$. Recommended therapy for obtaining good glycaemic control is intensive therapy including multiple daily doses of insulin, frequent blood glucose measurements, and regular Glycosylated Haemoglobin (HbAlc) monitoring [7,9-12]. Currently, less than $20 \%$ of adult type 1 diabetic patients in Sweden achieve good glycaemic control $(<7.0 \%)$, and around $25 \%$ have very poor glycaemic control $(>8.6 \%[13])$, as poor as when patients in studies have received only basal insulin once or twice a day without any prandial insulin [7]. In Sweden, patients with type 1 diabetes have free access to novel insulin analogues, self-measurement of blood glucose (glucose-monitoring strips and meters), HbAlc tests, while insulin pumps are reimbursed when glycaemic control is inadequate. 
Citation: Matuleviciene V, Attvall S, Ekelund M, Clements M, Dahlqvist S, et al. (2014) A Retrospective Study in 5,989 Patients with Type 1 Diabetes in 10 Outpatient Diabetes Clinics in Sweden of the Frequency of Measuring HbA1c in Clinical Practice. J Diabetes Metab 5: 377. doi:10.4172/2155-6156.1000377

Page 2 of 7

Since many patients with type 1 diabetes in Sweden have poor glycaemic control, despite the widespread availability of novel treatment strategies, it is possible that barriers exist achieving adherence with blood glucose measurements, achieving proper insulin dosing, or providing basic diabetes care.

To support the intensive treatment strategy, diabetes guidelines generally recommend visits to a diabetes educator or physician with HbAlc monitoring performed at least every third month in patients with inadequate glycaemic control [9-12]. To our knowledge there are few studies examining adherence to these guidelines in clinical practice. Therefore, we examined the frequency of visits to 10 outpatient diabetes clinics in Sweden that included HbA1c checks over a 5-year period and evaluated potential explanatory factors for more frequent glycaemic monitoring.

\section{Methods}

\section{Data source}

Data were obtained from an electronic medical records system (Diab-Base, Journalia AB, Sweden), which is used at 10 hospital-based diabetes clinics that treat adult outpatients (18 years or older) in Sweden [14]). Most clinics in Sweden have used Diab-Base since around the year 2000. The system has been described in detail and has been used in several studies of diabetes treatments among patients with both types 1 and 2 diabetes [14-18]. Briefly, the system includes information about risk factors, treatment, and complications that are recorded during clinical visits. All risk factor measurements, such as HbAlc, blood pressure, blood lipids, body mass index (BMI), type of diabetes, and insulin dose, are tracked electronically. In addition, type of insulin delivery, either continuous subcutaneous insulin infusion (CSII) or Multiple Daily Injections (MDI) can be tracked electronically, as along with information on diabetic complications.

\section{Current cohort and data analysis}

The current cohort included patients with type 1 diabetes studied from 1 January 2005 to 31 December 2009. The frequency of HbAlc measurements was assessed for all patients, as well as by calender year, diabetes outpatient clinic (also further on denoted care unit), and period of time when patients achieved good (HbAlc $\leq 7.0 \%)$ and inadequate glycemic control (HbA1c $>7.0 \%)$. Potential predictors for receiving a subsequent $\mathrm{HbAlc}$ check within 4 and 7 months after an HbAlc value $>7.0 \%$ were examined, including age, sex, type of insulin delivery (MDII or CSII), diabetes duration, HbA1c level, weight, BMI, insulin dose $(\mathrm{U} / \mathrm{kg})$, and care unit.

\section{Statistics}

The mean number of HbAlc checks for the entire cohort was calculated as the mean value resulting from the annual means of all HbAlc checks for each individual patient. The mean number of $\mathrm{HbAlc}$ checks during periods with an $\mathrm{HbAlc}>7.0 \%$ was calculated with the corresponding methodology during the periods of time when an $\mathrm{HbAlc}>7.0 \%$ was identified until a subsequent check identified a novel value $\leq 7.0 \%$. The corresponding methodology was similarly used to estimate the mean number of $\mathrm{HbAlc}$ checks during patient periods with $\mathrm{HbAlc} \leq 7.0 \%$.

To predict the likelihood of having an HbAlc check in 4 and 7 months following an $\mathrm{HbA} 1 \mathrm{c}>7.0 \%$ at any time during the study,
Generalized Estimating Equations (GEE) models with a compound symmetry covariance matrix were used to allow for adjustment of within-individual correlations [19]. Univariate GEE models were used to identify the statistically significant predictors that affected the outcome.

Stepwise logistic regression was used for selection of independent predictors that were statistically significant. Once variables were selected, the GEE models were performed including the selected variables to obtain the adjusted odds-ratios (OR), 95\% Confidence Intervals (CI) and associated p-values. Imputation of missing weight, $\mathrm{BMI}$, and insulin doses was performed by using last observation carried forward. All tests were two-tailed and conducted at the 0.05 significance level.

\section{Results}

In total, there were 5,989 patients with type 1 diabetes evaluated. Patient characteristics for the whole cohort at first visit during the years 2005 to 2009 as well as in relation to the number of annual HbAlc measurements are presented in Table 1a. Distribution of mean number of annual HbAlc measurements by care unit is given in Table $1 b$.

\begin{tabular}{|c|c|c|c|c|c|c|}
\hline & $\begin{array}{l}\text { Total } \\
(n=5989)\end{array}$ & $\begin{array}{l}<1 \\
(n=569)\end{array}$ & $\begin{array}{l}1-<2 \\
(n=2894)\end{array}$ & $\begin{array}{l}2-<3 \\
(n=2050)\end{array}$ & $\begin{array}{l}3-<4 \\
(n=371)\end{array}$ & $\begin{array}{l}>=4 \\
(n=105)\end{array}$ \\
\hline $\begin{array}{l}\text { Age } \\
\text { (years) }\end{array}$ & $\begin{array}{l}42.9 \\
(16.1) \\
\\
41.7 \\
(16.0 ; \\
89.5) \\
n=5989\end{array}$ & $\begin{array}{l}42.6 \\
(16.7) \\
\\
39.7 \\
(17.3 ; \\
87.1) \\
\\
\mathrm{n}=569\end{array}$ & $\begin{array}{l}43.2 \\
(16.0) \\
\\
41.7 \\
(16.2 ; \\
85.3) \\
\\
n=2894\end{array}$ & $\begin{array}{l}44.0 \\
(16.0) \\
44.1 \\
(16.2 ; \\
89.5) \\
n=2050\end{array}$ & $\begin{array}{l}37.4 \\
(14.9) \\
35.7 \\
(16.0 ; \\
79.4) \\
n=371\end{array}$ & $\begin{array}{l}37.4(15.3) \\
34.9(16.1 ; \\
78.4) \\
n=105\end{array}$ \\
\hline Sex & & & & & & \\
\hline Male & \begin{tabular}{|l}
3327 \\
$(55.6 \%)$
\end{tabular} & $\begin{array}{l}350 \\
(61.5 \%)\end{array}$ & $\begin{array}{l}1663 \\
(57.5 \%)\end{array}$ & $\begin{array}{l}1082 \\
(52.8 \%)\end{array}$ & $\begin{array}{l}179 \\
(48.2 \%)\end{array}$ & $53(50.5 \%)$ \\
\hline Female & \begin{tabular}{|l}
2662 \\
$(44.4 \%)$
\end{tabular} & $\begin{array}{l}219 \\
(38.5 \%)\end{array}$ & $\begin{array}{l}1231 \\
(42.5 \%)\end{array}$ & $\begin{array}{l}968 \\
(47.2 \%)\end{array}$ & $\begin{array}{l}192 \\
(51.8 \%)\end{array}$ & $52(49.5 \%)$ \\
\hline CSII & & & & & & \\
\hline No & \begin{tabular}{|l}
4724 \\
$(78.9 \%)$
\end{tabular} & $\begin{array}{l}506 \\
(88.9 \%)\end{array}$ & $\begin{array}{l}2423 \\
(83.7 \%)\end{array}$ & $\begin{array}{l}1506 \\
(73.5 \%)\end{array}$ & $\begin{array}{l}223 \\
(60.1 \%)\end{array}$ & 66 (62.9\%) \\
\hline Yes & $\begin{array}{l}1265 \\
(21.1 \%)\end{array}$ & $\begin{array}{l}63 \\
(11.1 \%)\end{array}$ & $\begin{array}{l}471 \\
(16.3 \%)\end{array}$ & $\begin{array}{l}544 \\
(26.5 \%)\end{array}$ & $\begin{array}{l}148 \\
(39.9 \%)\end{array}$ & $39(37.1 \%)$ \\
\hline $\begin{array}{l}\text { Diabetes } \\
\text { duration } \\
\text { (years) }\end{array}$ & $\begin{array}{l}20.9 \\
(14.8) \\
\\
19.1 \\
(-0.9 \\
78.4) \\
n=5636\end{array}$ & $\begin{array}{l}21.9 \\
(14.7) \\
20.4 \\
\\
(-0.0 ; \\
68.7) \\
\mathrm{n}=502\end{array}$ & $\begin{array}{l}21.1 \\
(14.6) \\
19.1 \\
(-0.9 ; \\
78.4) \\
n=2719\end{array}$ & $\begin{array}{l}21.5 \\
(15.1) \\
\\
20.2 \\
(-0.9 ; \\
69.1) \\
n=1960\end{array}$ & $\begin{array}{l}15.9 \\
(14.2) \\
13.6 \\
\\
(-0.2 ; \\
59.1) \\
n=358\end{array}$ & $\begin{array}{l}15.8(15.0) \\
14.3 \quad(-0.0 ; \\
55.2) \\
n=97\end{array}$ \\
\hline $\begin{array}{l}\mathrm{BMI} \\
\left(\mathrm{kg} / \mathrm{m}^{2}\right)^{*}\end{array}$ & $\begin{array}{l}25.3 \\
(12.1) \\
\\
25.0 \\
(14.0 ; \\
806.0)\end{array}$ & $\begin{array}{l}25.0 \\
(4.0) \\
24.0 \\
\\
(16.0 ; \\
43.0)\end{array}$ & $\begin{array}{l}25.3 \\
(16.7) \\
25.0 \\
\\
(14.0 ; \\
806.0)\end{array}$ & $\begin{array}{l}25.2(3.9) \\
25.0 \\
(15.0 ; \\
42.0) \\
n=1615\end{array}$ & $\begin{array}{l}25.1 \\
(4.1) \\
\\
24.0 \\
(15.0 ; \\
42.0)\end{array}$ & $\begin{array}{l}26.3(5.4) \\
26.0(17.0 ; \\
46.0) \\
n=55\end{array}$ \\
\hline
\end{tabular}


Citation: Matuleviciene V, Attvall S, Ekelund M, Clements M, Dahlqvist S, et al. (2014) A Retrospective Study in 5,989 Patients with Type 1 Diabetes in 10 Outpatient Diabetes Clinics in Sweden of the Frequency of Measuring HbA1c in Clinical Practice. J Diabetes Metab 5: 377. doi:10.4172/2155-6156.1000377

Page 3 of 7

\begin{tabular}{|c|c|c|c|c|c|c|}
\hline & $\mathrm{n}=4643$ & $n=428$ & $n=2292$ & & $n=253$ & \\
\hline $\begin{array}{l}\text { Weight } \\
(\mathrm{kg})^{*}\end{array}$ & $\begin{array}{l}75.7 \\
(14.1) \\
74.6 \\
(32.0 ; \\
150.0) \\
n=4979\end{array}$ & $\begin{array}{l}76.3 \\
(15.0) \\
75.0 \\
\\
(41.5 ; \\
148.8) \\
n=458\end{array}$ & $\begin{array}{l}75.7 \\
(14.1) \\
74.5 \\
(32.0 ; \\
150.0) \\
n=2444\end{array}$ & $\begin{array}{l}75.6 \\
(13.8) \\
74.7 \\
(43.6 ; \\
140.1) \\
n=1731\end{array}$ & $\begin{array}{l}74.3 \\
(14.2) \\
74.0 \\
\\
(44.4 ; \\
132.0) \\
n=280\end{array}$ & $\begin{array}{l}77.1(18.0) \\
75.2(47.3 ; \\
123.0) \\
n=66\end{array}$ \\
\hline \begin{tabular}{|l|} 
Insulin \\
dose \\
(unit/kg)*
\end{tabular} & $\begin{array}{l}0.63 \\
(0.26) \\
\\
0.60 \\
(0.00 ; \\
5.80) \\
\mathrm{n}=4762\end{array}$ & $\begin{array}{l}0.66 \\
(0.28) \\
\\
0.60 \\
(0.00 ; \\
2.40) \\
n=433\end{array}$ & $\begin{array}{l}0.62 \\
(0.25) \\
0.60 \\
(0.00 ; \\
5.80) \\
n=2343\end{array}$ & $\begin{array}{l}0.63 \\
(0.25) \\
0.60 \\
(0.00 ; \\
3.90) \\
n=1674\end{array}$ & $\begin{array}{l}0.64 \\
(0.31) \\
0.60 \\
\\
(0.00 ; \\
3.40) \\
\\
n=257\end{array}$ & $\begin{array}{l}0.74(0.31) \\
0.70(0.30 ; \\
1.70) \\
n=55\end{array}$ \\
\hline
\end{tabular}

For categorical variables $\mathrm{n}(\%)$ is presented.

For continuous variables Mean (SD) / Median / (Min; Max) / n= is presented

* Missing values are imputed by using last observation carry forward (LOCF) in case patient existed in DiabBase before 2005.

Table 1a: Patient characteristics at first visit during years 2005 and 2009 in DiabBase in total and in relation to the number of mean number of annual HbAlc measurements performed during same period.

\begin{tabular}{|l|l|l|l|l|l|}
\hline & $\begin{array}{l}<\mathbf{1} \\
(\mathbf{n = 5 6 9 )}\end{array}$ & $\begin{array}{l}\mathbf{1 - < 2} \\
(\mathbf{n = 2 8 9 4 )}\end{array}$ & $\begin{array}{l}\mathbf{2 - < 3} \\
\mathbf{( n = 2 0 5 0 )}\end{array}$ & $\begin{array}{l}\mathbf{3}-<\mathbf{4} \\
(\mathbf{n = 3 7 1})\end{array}$ & $\begin{array}{l}\mathbf{> = 4} \\
(\mathbf{n = 1 0 5})\end{array}$ \\
\hline Unit 1 & $6.1 \%$ & $35.6 \%$ & $53.8 \%$ & $4.2 \%$ & $0.4 \%$ \\
\hline Unit 2 & $16.3 \%$ & $58.4 \%$ & $16.9 \%$ & $5.6 \%$ & $2.8 \%$ \\
\hline Unit 3 & $12.2 \%$ & $54.2 \%$ & $29.1 \%$ & $3.7 \%$ & $0.8 \%$ \\
\hline Unit 4 & $3.8 \%$ & $36.0 \%$ & $48.0 \%$ & $9.0 \%$ & $3.2 \%$ \\
\hline Unit 5 & $7.5 \%$ & $58.7 \%$ & $31.5 \%$ & $2.4 \%$ & $0.0 \%$ \\
\hline Unit 6 & $10.9 \%$ & $56.0 \%$ & $26.2 \%$ & $5.0 \%$ & $1.9 \%$ \\
\hline Unit 7 & $5.6 \%$ & $30.0 \%$ & $52.3 \%$ & $10.9 \%$ & $1.2 \%$ \\
\hline Unit 8 & $12.2 \%$ & $56.5 \%$ & $26.4 \%$ & $3.8 \%$ & $1.1 \%$ \\
\hline Unit 9 & $7.6 \%$ & $53.2 \%$ & $32.5 \%$ & $6.1 \%$ & $0.6 \%$ \\
\hline Unit 10 & $3.3 \%$ & $20.9 \%$ & $39.6 \%$ & $22.5 \%$ & $13.7 \%$ \\
\hline
\end{tabular}

Table 1b: Distribution of mean number of annual HbAlc measurements performed during years 2005-2009 by care unit

The mean age of patients with 3 or more HbAlc checks per year was 37.4 years, compared to 42.9 years for the entire cohort. Females comprised $44.4 \%$ of the entire cohort, compared to $51.8 \%$ and $49.5 \%$ among patients with 3 to 4 annual HbAlc checks and 4 or more annual HbA1c checks, respectively, $\mathrm{p}=0.0022$ for test between $<3$ vs. $\geq 3 \mathrm{HbAlc}$ checks. Diabetes duration was 20.9 years among the entire cohort, compared to 15.9 and 15.8 years, respectively, in patients with 3 to 4 and 4 or more HbA1c checks per year, $\mathrm{p}<0.0001$ for test vs. $<3$ HbAlc checks. Among the entire cohort, $21.1 \%$ had CSII, compared to $39.9 \%$ and $37.1 \%$, respectively, in patients with 3 to 4 and 4 or more annual HbAlc checks, $\mathrm{p}<0.0001$ for test vs. $<3 \mathrm{HbAlc}$ checks. In unit 10 there were $36.2 \%$ of patients having 3 or more HbAlc checks per year, $\mathrm{p}<0.0001$ for test vs. $<3 \mathrm{HbA1c}$ checks, whereas fewer than $10 \%$ of patients had 3 or more annual HbAlc checks in most other care units (Table 1b).

The mean annual number of HbAlc measurements increased moderately, from 1.72 in 2005 to 1.90 in $2009, \mathrm{p}=0.0021$ for trend over years, with a mean of 1.78 over the study period (Table 2 ). There was an increase $\mathrm{p}<0.0001$ in the mean $\mathrm{HbAlc}$ level, from $7.92 \%$ in 2005 to $8.05 \%$ in 2009 (Table 2). The proportion of patients reaching a target HbAlc of $\leq 7.0 \%$ varied, from a low of $18.6 \%$ in 2009 to a high of $22.9 \%$ in 2007 (Table 2).

\begin{tabular}{|c|c|c|c|}
\hline & $\begin{array}{l}\text { Mean number of } \\
\text { yearly visit }\end{array}$ & $\begin{array}{l}\text { Mean HbA1c } \\
(\%, \text { NGSP) }\end{array}$ & $\begin{array}{l}\text { First yearly } \\
\text { HbA1c<=7 } \\
\text { (\%, NGSP) }\end{array}$ \\
\hline Year 2005 & $\begin{array}{l}1.72(1.11) \\
2.00(0.00 ; 8.00) \\
n=4852\end{array}$ & $\begin{array}{l}7.92(1.24) \\
7.83 \quad(4.58 ; 16.29) \\
n=4255\end{array}$ & $912(21.4 \%)$ \\
\hline Year 2006 & $\begin{array}{l}1.74(1.11) \\
2.00(0.00 ; 9.00) \\
n=4937\end{array}$ & $\begin{array}{l}7.94(1.25) \\
7.87 \quad(4.53 ; 14.57) \\
n=4392\end{array}$ & 927 (21.1\%) \\
\hline Year 2007 & $\begin{array}{l}1.79(1.11) \\
2.00(0.00 ; 14.00) \\
n=5075\end{array}$ & $\begin{array}{l}7.91(1.27) \\
7.78 \quad(4.43 ; 14.66) \\
n=4565\end{array}$ & $1047(22.9 \%)$ \\
\hline Year 2008 & $\begin{array}{l}1.89(1.12) \\
2.00(0.00 ; 11.00) \\
n=5149\end{array}$ & $\begin{array}{l}8.00(1.25) \\
7.87 \quad(4.62 ; 15.81) \\
n=4738\end{array}$ & $965(20.4 \%)$ \\
\hline Year 2009 & $\begin{array}{l}1.90(1.15) \\
2.00(0.00 ; 10.00) \\
n=5092\end{array}$ & $\begin{array}{l}8.05(1.27) \\
7.92 \quad(4.15 ; 14.57) \\
n=4769\end{array}$ & 888 (18.6\%) \\
\hline $\begin{array}{l}\text { Mean } \\
\text { during } \\
\text { 2005-2009 }\end{array}$ & $\begin{array}{l}1.78(0.80) \\
1.80(0.00 ; 9.00) \\
n=5989\end{array}$ & $\begin{array}{l}8.00(1.21) \\
7.90 \quad(4.43 ; 14.64) \\
n=5854\end{array}$ & \\
\hline
\end{tabular}

For categorical variables $\mathrm{n}(\%)$ is presented.

For continuous variables Mean (SD)/Median/(Min; Max)/n=is presented. For continuous variables Mean (SD)/Median/(Min; Max)/n=is presented.

Table 2: Distribution of number of yearly visits, HbAlc levels and HbAlc $<=7$ (\%, NGSP) by calendar year

The mean number of $\mathrm{HbAlc}$ measurements during time periods where $\mathrm{HbAlc}$ was $>7.0 \%$ and $\leq 7.0 \%$ was 1.83 and 1.58 , respectively. In $35.4 \%$ of cases the next HbAlc check following an $\mathrm{HbA1c}>7 \%$ was performed within 4 months. Table 3 contains the univariable and multivariable predictors for a novel HbAlc check within 4 and 7 months, respectively, after an HbAlc $>7.0 \%$. In multivariable models, younger age, female sex, shorter diabetes duration, treatment with CSII, later calendar year, lower weight, higher $\mathrm{HbAlc}$, and care unit were independently associated with an HbAlc check within 4 months. With the exception of younger age, the same variables were independent predictors of an HbAlc check within 7 months. The odds ratios for an HbAlc check within 4 and 7 months was 1.57 (1.46-1.69) 
Citation: Matuleviciene V, Attvall S, Ekelund M, Clements M, Dahlqvist S, et al. (2014) A Retrospective Study in 5,989 Patients with Type 1 Diabetes in 10 Outpatient Diabetes Clinics in Sweden of the Frequency of Measuring HbA1c in Clinical Practice. J Diabetes Metab 5: 377. doi:10.4172/2155-6156.1000377

Page 4 of 7

and 1.50 (1.40-1.62,) respectively, for patients using CSII versus MDI, unit increase in HbA1c, and 2.92 (2.50-3.42) and 2.88 (2.40-3.47) for the OR was $1.37(1.34-1.41)$ and $1.21(1.17-1.24)$ for each 1 percentage the care unit with the highest OR versus all other care units.

\begin{tabular}{|c|c|c|c|c|c|c|c|c|}
\hline \multirow[b]{3}{*}{ Variable } & \multicolumn{4}{|c|}{$\begin{array}{l}\text { Probability of having a novel } \mathrm{HbA1c} \text { check within } 4 \text { months after } \\
\text { an } \mathrm{HbA} 1 \mathrm{c}>7 \%\end{array}$} & \multicolumn{4}{|c|}{$\begin{array}{l}\text { Probability of having a novel } \mathrm{HbA} 1 \mathrm{c} \text { check within } 7 \text { months after } \\
\text { an } \mathrm{HbA} 1 \mathrm{c}>7 \%\end{array}$} \\
\hline & \multicolumn{2}{|l|}{ Univariable } & \multicolumn{2}{|c|}{ Multivariable } & \multicolumn{2}{|l|}{ Univariable } & \multicolumn{2}{|c|}{ Multivariable } \\
\hline & $\begin{array}{l}\text { OR } \\
(95 \% \mathrm{Cl})\end{array}$ & $p$-value & $\begin{array}{l}\text { OR } \\
(95 \% \mathrm{Cl})\end{array}$ & $p$-value & $\begin{array}{l}\text { OR } \\
(95 \% \mathrm{Cl})\end{array}$ & $p$-value & $\begin{array}{l}\text { OR } \\
(95 \% \mathrm{Cl})\end{array}$ & $p$-value \\
\hline $\begin{array}{l}\text { Sex } \\
2=\text { Female }) \quad(1=\text { Male; }\end{array}$ & $\begin{array}{l}1.20 \\
(1.12-1.28)\end{array}$ & $<.0001$ & $\begin{array}{l}1.12 \\
(1.05-1.21)\end{array}$ & 0.0017 & $\begin{array}{l}1.19 \\
(1.12-1.27)\end{array}$ & $<.0001$ & $\begin{array}{l}1.12 \\
(1.05-1.20)\end{array}$ & 0.0007 \\
\hline $\begin{array}{l}\text { Current age (by } 10 \\
\text { years) }\end{array}$ & $\begin{array}{l}0.87 \\
(0.85-0.89)\end{array}$ & $<.0001$ & $\begin{array}{l}0.94 \\
(0.92-0.96)\end{array}$ & $<.0001$ & $\begin{array}{l}0.95 \\
(0.93-0.97)\end{array}$ & $<.0001$ & & \\
\hline $\begin{array}{l}\text { Diabetes duration (by } \\
10 \text { years) }\end{array}$ & $\begin{array}{l}0.89 \\
(0.87-0.91)\end{array}$ & $<.0001$ & $\begin{array}{l}0.93 \\
(0.91-0.96)\end{array}$ & $<.0001$ & $\begin{array}{l}0.97 \\
(0.95-0.99)\end{array}$ & 0.0060 & $\begin{array}{l}0.97 \\
(0.95-0.99)\end{array}$ & 0.0098 \\
\hline CSII (0=No; $1=Y e s)$ & $\begin{array}{l}1.65 \\
(1.54-1.78)\end{array}$ & $<.0001$ & $\begin{array}{l}1.57 \\
(1.46-1.69)\end{array}$ & $<.0001$ & $\begin{array}{l}1.54 \\
(1.43-1.66)\end{array}$ & $<.0001$ & $\begin{array}{l}1.50 \\
(1.40-1.62)\end{array}$ & $<.0001$ \\
\hline $\begin{array}{l}\text { Current weight (by } 10 \\
\mathrm{~kg} \text { ) }\end{array}$ & $\begin{array}{l}0.97 \\
(0.94-1.00)\end{array}$ & 0.030 & $\begin{array}{l}0.97 \\
(0.94-1.00)\end{array}$ & 0.023 & $\begin{array}{l}0.98 \\
(0.97-1.00)\end{array}$ & 0.048 & $\begin{array}{l}0.98 \\
(0.96-1.00)\end{array}$ & 0.027 \\
\hline Current BMI $\left(\mathrm{kg} / \mathrm{m}^{2}\right)$ & $\begin{array}{l}0.99 \\
(0.98-1.00)\end{array}$ & 0.039 & & & $\begin{array}{l}1.00 \\
(0.99-1.00)\end{array}$ & 0.56 & & \\
\hline $\begin{array}{l}\text { Current insulin dose } \\
\text { (unit/kg) }\end{array}$ & $\begin{array}{l}0.99 \\
(0.88-1.11)\end{array}$ & 0.82 & & & $\begin{array}{l}0.99 \\
(0.89-1.11)\end{array}$ & 0.89 & & \\
\hline Current calendar year & $\begin{array}{l}1.13 \\
(1.11-1.15)\end{array}$ & $<.0001$ & $\begin{array}{l}1.14 \\
(1.12-1.17)\end{array}$ & $<.0001$ & $\begin{array}{l}1.17 \\
(1.15-1.19)\end{array}$ & $<.0001$ & $\begin{array}{l}1.18 \\
(1.16-1.20)\end{array}$ & $<.0001$ \\
\hline $\begin{array}{l}\text { Current HbA1c }(\%, \\
\text { NGSP) }\end{array}$ & $\begin{array}{l}1.38 \\
(1.34-1.41)\end{array}$ & $<.0001$ & $\begin{array}{l}1.37 \\
(1.34-1.41)\end{array}$ & $<.0001$ & $\begin{array}{l}1.22 \\
(1.19-1.25)\end{array}$ & $<.0001$ & $\begin{array}{l}1.21 \\
(1.17-1.24)\end{array}$ & $<.0001$ \\
\hline Unit $1(0=\mathrm{No} ; 1=\mathrm{Yes})$ & $\begin{array}{l}0.85 \\
(0.72-1.00)\end{array}$ & 0.056 & & & $\begin{array}{l}1.60 \\
(1.40-1.84)\end{array}$ & $<.0001$ & $\begin{array}{l}1.94 \\
(1.68-2.24)\end{array}$ & $<.0001$ \\
\hline Unit $2(0=\mathrm{No} ; 1=\mathrm{Yes})$ & $\begin{array}{l}1.14 \\
(1.00-1.31)\end{array}$ & 0.052 & & & $\begin{array}{l}0.64 \\
(0.56-0.72)\end{array}$ & $<.0001$ & $\begin{array}{l}0.80 \\
(0.70-0.91)\end{array}$ & 0.0007 \\
\hline Unit $3(0=\mathrm{No} ; 1=\mathrm{Yes})$ & $\begin{array}{l}0.80 \\
(0.74-0.87)\end{array}$ & $<.0001$ & $\begin{array}{l}0.86 \\
(0.78-0.96)\end{array}$ & 0.0061 & $\begin{array}{l}0.77 \\
(0.72-0.82)\end{array}$ & $<.0001$ & & \\
\hline Unit $4(0=\mathrm{No} ; 1=\mathrm{Yes})$ & $\begin{array}{l}1.63 \\
(1.48-1.80)\end{array}$ & $<.0001$ & $\begin{array}{l}1.56 \\
(1.38-1.77)\end{array}$ & $<.0001$ & $\begin{array}{l}1.64 \\
(1.48-1.82)\end{array}$ & $<.0001$ & $\begin{array}{l}1.92 \\
(1.72-2.15)\end{array}$ & $<.0001$ \\
\hline Unit 5 ( $0=\mathrm{No}$; $1=\mathrm{Yes})$ & $\begin{array}{l}0.56 \\
(0.47-0.65)\end{array}$ & $<.0001$ & $\begin{array}{l}0.55 \\
(0.46-0.65)\end{array}$ & $<.0001$ & $\begin{array}{l}0.94 \\
(0.84-1.06)\end{array}$ & 0.33 & & \\
\hline Unit $6(0=\mathrm{No} ; 1=\mathrm{Yes})$ & $\begin{array}{l}0.83 \\
(0.76-0.92)\end{array}$ & 0.0003 & $\begin{array}{l}0.82 \\
(0.73-0.93)\end{array}$ & 0.0012 & $\begin{array}{l}0.68 \\
(0.62-0.74)\end{array}$ & $<.0001$ & $\begin{array}{l}0.85 \\
(0.78-0.93)\end{array}$ & 0.0005 \\
\hline Unit $7(0=\mathrm{No} ; 1=\mathrm{Yes})$ & $\begin{array}{l}1.17 \\
(1.08-1.26)\end{array}$ & 0.0002 & $\begin{array}{l}1.13 \\
(1.02-1.26)\end{array}$ & 0.024 & $\begin{array}{l}1.74 \\
(1.59-1.89)\end{array}$ & $<.0001$ & $\begin{array}{l}1.91 \\
(1.75-2.09)\end{array}$ & $<.0001$ \\
\hline Unit $8(0=\mathrm{No} ; 1=\mathrm{Yes})$ & $\begin{array}{l}0.79 \\
(0.69-0.90)\end{array}$ & 0.0004 & $\begin{array}{l}0.75 \\
(0.65-0.87)\end{array}$ & 0.0002 & $\begin{array}{l}0.75 \\
(0.67-0.85)\end{array}$ & $<.0001$ & & \\
\hline Unit $9(0=\mathrm{No} ; 1=\mathrm{Yes})$ & $\begin{array}{l}0.91 \\
(0.78-1.06)\end{array}$ & 0.25 & & & $\begin{array}{l}0.94 \\
(0.82-1.07)\end{array}$ & 0.34 & & \\
\hline
\end{tabular}


Citation: Matuleviciene V, Attvall S, Ekelund M, Clements M, Dahlqvist S, et al. (2014) A Retrospective Study in 5,989 Patients with Type 1 Diabetes in 10 Outpatient Diabetes Clinics in Sweden of the Frequency of Measuring HbA1c in Clinical Practice. J Diabetes Metab 5: 377. doi:10.4172/2155-6156.1000377

Page 5 of 7

\begin{tabular}{l}
\begin{tabular}{|l|l|l|l|l|l|l|l|}
\hline Unit $10(0=$ No; 1=Yes) & $\begin{array}{l}2.83 \\
(2.45-3.26)\end{array}$ & $<.0001$ & $\begin{array}{l}2.92 \\
(2.50-3.42)\end{array}$ & $<.0001$ & $\begin{array}{l}2.41 \\
(2.00-2.89)\end{array}$ & $<.0001$ & $\begin{array}{l}2.88 \\
(2.40-3.47)\end{array}$ \\
\hline
\end{tabular} \\
$\begin{array}{l}\text { Generalized Estimating Equation (GEE) models have been used as they allow for adjustment of within-individual correlation. } \\
\text { Odds-ratio (OR) is describing the effect of the predictor on the outcome variable per } 1 \text { unit except for the variables current age, } \\
\text { diabetes duration and current weight for which OR is expressing the effect by } 10 \text { units. }\end{array}$ \\
The OR for a unit is compared is expressing the effect compared to all other units. \\
\hline
\end{tabular}

Table 3: Probability of having a novel HbAlc check within 4 months and 7 months respectively after an HbAlc>7 (\%, NGSP), univariable and multivariable GEE model.

The relationship between $\mathrm{HbA1c}$ level and probability of having an HbAlc check within 4 months indicated a monotonically increasing probability by higher HbA1c up to $11 \%$ (Figure 1a). The probability of having an HbAlc check was higher among patients with diabetes duration less than 10 years, but no clear pattern was seen beyond 10 years (Figure 1b).

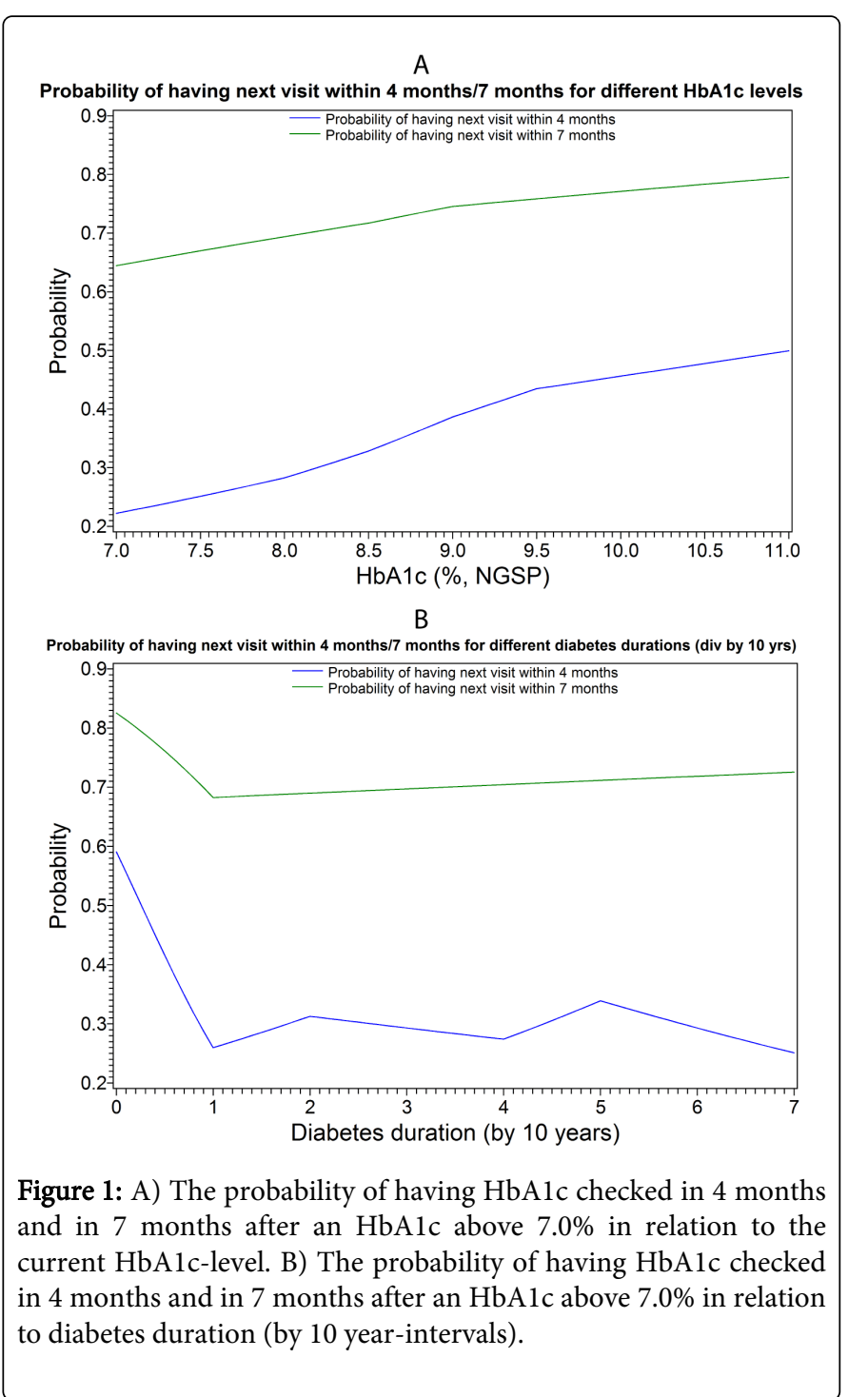

Figure 1: A) The probability of having HbAlc checked in 4 months and in 7 months after an HbAlc above $7.0 \%$ in relation to the current HbAlc-level. B) The probability of having HbAlc checked to diabetes duration (by 10 year-intervals).

\section{Discussion}

This retrospective study of 5989 patients with type 1 diabetes from 10 outpatient diabetes clinics in Sweden during years 2005-2009, shows that annual HbA1c checks were performed less frequently than advocated in clinical guidelines. During the follow-up period, there were 1.75 annual HbAlc checks, on average, during patient periods with $\mathrm{HbAlc} \geq 7.0 \%$, while clinical guidelines suggest a check at least every 3 rd month after the initial elevated value. In only $35.4 \%$ of cases the next $\mathrm{HbAlc}$ check following an $\mathrm{HbAlc}>7 \%$ was performed within 4 months. The frequency of annual HbAlc checks was significantly higher for patients treated with CSII compared to MDI, younger individuals compared to older, those with shorter diabetes duration, females, patients with higher $\mathrm{HbAlc}$, and for certain care units. The probability of having an $\mathrm{HbAlc}$ check within 4 months after an HbAlc check with a value $\geq 7.0 \%$ was approximately $50 \%$ greater in individuals treated with CSII compared to MDI. Moreover, the probability of a follow-up HbAlc check at 4 months in patients with inadequate glycaemic control differed between certain care units, with a nearly three-fold increased likelihood among the care unit performing the most annual checks, when compared to the mean number of checks in other care units.

To our knowledge, there is only a single study examining the frequency of HbAlc measurements in patients with type 1 diabetes [20]. In Germany and the UK, electronic medical records were examined from 1,910 and 1,500 patients with type 1 diabetes, respectively, treated in the primary care setting. Patients received, on average, 1.1 annual HbAlc checks in Germany and 2.0 annual checks in the U.K., and investigators concluded that HbAlc checks were underused in both countries. However, we found no previous work examining potential predictors for receiving more frequent annual $\mathrm{HbAlc}$ checks in patients with type 1 diabetes, such as those reported here (e.g., CSII and care unit). Recent studies of the frequency of HbAlc measurements in patients with type 2 diabetes or without specifying the type of diabetes, have reported that HbAlc checks are underused in the UK and Australia, without generally examining various predictors for more frequent HbA1c checks [21,22].

One possible explanation for type 1 diabetes patients receiving relatively few $\mathrm{HbAlc}$ checks at diabetes care units in Sweden could be a general lack of resources. However, insulin are free, as are glucose monitoring strips, HbAlc tests and insulin pumps if MDI is not used to target good glycaemic control, which is distinguishable from many other countries. Another more likely explanation may therefore be that the number of visits and checks of HbAlc have not been a proper focus of attention in evaluating the quality of diabetes care. In Sweden, the frequency of visits for diabetes care and HbAlc checks are not recorded in the national diabetes registry or in various economic 
programs that support care units [13]. Since the mean HbAlc-level during recent years has increased on a national level in patients with type 1 diabetes in Sweden [13], despite increased use of advanced therapies such as CSII, it is possible that there may be problems in the basic care structure for intensive glycaemic therapy. In addition to fewer visits including HbAlc checks, as shown in this study, compliance with regular blood glucose measurements and insulin dosing may also explain these findings.

The number of blood glucose (BG) measurements performed in patients with type 1 diabetes has shown a strong association to the HbAlc-level [23,24]. Good compliance with BG checks has been associated with larger drops in HbAlc than novel therapies such as CSII or insulin analogues [14,23-27]. This may also be reasonable from a clinical perspective since dosage of insulin will not be optimised by bolus correction if BG is not measured before meals. There are yet no studies in Sweden of the general frequency of BG measurements in patients with type 1 diabetes, but our clinical experience is that it is difficult for many patients to comply with BG measurements 4 times per day as advocated in guidelines. One hypothesis is therefore that a reason why $\mathrm{HbAlc}$ is not improving in Sweden in spite of patients receiving more modern treatments can be general barriers to adhere to intensive treatment strategies. More frequent clinical visits to diabetes outpatient clinics than the relatively low rate shown here may be essential in supporting patients to comply with BG measurements and insulin dosage, besides other general treatment strategies included in modern diabetes care.

The likelihood of having an HbAlc check within 4 months was approximately $50 \%$ greater for patients treated with CSII compared to MDI. It is noteworthy that although if the lower bound of the $95 \% \mathrm{CI}$ would be true, there was an OR of 1.46 supporting a greater likelihood in the probability of having $\mathrm{HbAlc}$ checked for patients treated with CSII compared to MDI. Moreover, when evaluating the likelihood of receiving an $\mathrm{HbAlc}$ check within 7 months, the OR was 1.50 in favour of CSII also supporting this difference in availability of care depending on treatment. One possible explanation is that patients on CSII need more visits for support regarding technical issues and complications with the therapy. However, it does not seem reasonable that patients with MDI should receive considerably less diabetes care: also noticing that MDI is a much less expensive therapy. The variation found in $\mathrm{HbAlc}$ checks in relation to care unit may implicate a need for recommendations on the number of visits including HbAlc checks in quality registers and be a focus in the care at outpatient diabetic clinics. Although relatively few HbAlc checks were performed, it was encouraging that more checks existed the higher the HbAlc, since it could be hypothesized that patients with very high $\mathrm{HbAlc}$ would have had fewer checks due to worse adherence to patient visits. The fact that patients with shorter diabetes duration had more checks of $\mathrm{HbAlc}$ seems appropriate since we could show that this was mainly contributed by more visits during the first years after diagnosis, when more attention and education to the patient is generally needed.

The present study is limited in that psychosocial variables were not available for study. It is possible that various psychosocial variables may be related to the probability of having an HbAlc check.

Family situation, working situation, educational level, area of living (rural/urban) could possibly all be related to the willingness and possibility to attend clinical visits. Today, some psychosocial variables exist in the Diab-Base system. For future research, care units could be promoted to register these variables to a greater extent, and the number of variables could possibly be extended. Another limitation is that we did not have information whether patients were scheduled for a check of HbAlc but did not attend or whether patients did not receive a visit. However, from clinical experience of diabetes care in Sweden the absolute majority of patients attend their scheduled visits. Our results are therefore probably explained mainly by care givers not giving patients the opportunity to visits in accordance with guidelines. To improve availability of HbAlc checks, increased resources from care givers may be essential but the responsibility for the individual physician and diabetes educator may also be of concern. Another variable that may have been of interest to evaluate is hypoglycaemia, but this is difficult to record properly in clinical practice for several reasons and the data were judged to be insufficient in the current electronical medical record system. Our finding that more checks were performed in women must be interpreted with caution since it was not possible to exclude periods of pregnancy in all instances, which may result in unknown confounder, although the total time of pregnancy is likely very small compared to all patient years without pregnancy. We did not evaluate explicit visits but the checks of HbAlc per se, but it is noteworthy that in Sweden HbAlc evaluations are in the absolute majority of cases performed in connection to a visit to a physician or diabetes educator.

In our analyses we used the time frame of having an $\mathrm{HbAlc}$ check within 4 months and not 3 months as advocated in guidelines. The reason is that it may be difficult to schedule visits at exactly 3 months in clinical practice due to practical reasons such as family situation or work situation for the patient. The time frame of one extra month was set relatively conservatively to not overestimate patients not having an $\mathrm{HbAlc}$ check in accordance with guidelines. In correspondence when evaluating patient characteristics associated to not having an $\mathrm{HbAlc}$ check even in 6 months, we used an extended time frame by 1 month.

In conclusion, patients with type 1 diabetes at 10 outpatient diabetes clinics in Sweden had fewer HbAlc checks than advocated in clinical guidelines. More frequent $\mathrm{HbAlc}$ checks may improve glycaemic control in the Swedish population. Patients with MDI need to attain extra attention. The frequency of HbAlc checks varies strongly by care unit and needs to be evaluated at the individual diabetes outpatient clinic. Our literature review shows that there previously has been little focus on evaluating the availability of the basic diabetes care in patients with type 1 diabetes. The basic support in diabetes care is probably most crucial in reducing diabetic complications and to give full support to novel therapies to obtain maximal benefit and from a safety perspective.

\section{Acknowledgements}

We want to thank all staff working with Diab-Base collecting data used for the current study. This study was supported by a grant from the Region of VästraGötaland, Sweden and Anna Cederbergs Foundation. The study was financed by grants from the Swedish state, under the agreement between the Swedish government and the county councils concerning economic support of research and education of doctors (ALF-agreement).

\section{Author Disclosure Statement}

Marcus Lind has been a consultant or received honoraria from Medtronic and Novonordisk and participated in advisory boards for Novonordisk. Marcus Lind has received research grants from DexCom and Novonordisk. Other authors declare no conflicts of interest. 
Citation: Matuleviciene V, Attvall S, Ekelund M, Clements M, Dahlqvist S, et al. (2014) A Retrospective Study in 5,989 Patients with Type 1 Diabetes in 10 Outpatient Diabetes Clinics in Sweden of the Frequency of Measuring HbA1c in Clinical Practice. J Diabetes Metab 5: 377. doi:10.4172/2155-6156.1000377

Page 7 of 7

\section{References}

1. Whiting DR, Guariguata L, Weil C, Shaw J (2011) IDF diabetes atlas: global estimates of the prevalence of diabetes for 2011 and 2030. Diabetes Res ClinPract 94: 311-321.

2. Imkampe AK, Gulliford MC (2011) Trends in Type 1 diabetes incidence in the UK in 0- to 14-year-olds and in 15- to 34-year-olds, 1991-2008. Diabet Med 28: 811-814.

3. Galler A, Stange T, Müller G, Näke A, Vogel C, et al. (2010) Incidence of childhood diabetes in children aged less than 15 years and its clinical and metabolic characteristics at the time of diagnosis: data from the Childhood Diabetes Registry of Saxony, Germany. Horm Res Paediatr 74: 285-291.

4. Ragnar Hanås (2008) Typ 1 Diabetes hos barn, ungdomarochungavuxna - Hur du blir expert på din egen diabetes (Type 1 Diabetes in children, youth and young adults - How you become an expert on your diabetes).

5. Menzin J, Korn JR, Cohen J, Lobo F, Zhang B, et al. (2010) Relationship between glycemic control and diabetes-related hospital costs in patients with type 1 or type 2 diabetes mellitus. J Manag Care Pharm 16: 264-275.

6. McKinlay J, Marceau L (2000) US public health and the 21st century: diabetes mellitus. Lancet 356: 757-761.

7. Diabetes Control and Complications Trial Research Group (1993) The effect of intensive treatment of diabetes on the development and progression of long-term complications in insulin-dependent diabetes mellitus. The Diabetes Control and Complications Trial Research Group. N Engl J Med 329: 977-986.

8. Nathan DM, Cleary PA, Backlund JY, Genuth SM, Diabetes Control and Complications Trial/Epidemiology of Diabetes Interventions and Complications (DCCT/EDIC) Study Research Group (2005) Intensive diabetes treatment and cardiovascular disease in patients with type 1 diabetes. N Engl J Med 353: 2643-2653.

9. American Diabetes Association (2014) Standards of medical care in diabetes--2014. Diabetes Care 37 Suppl 1: S14-80.

10. Type 1 diabetes: Diagnosis and management of type 1 diabetes in children, young people and adults. Available at: http:// egap.evidence.nhs.uk/type-1-diabetes-cg15/guidance\#blood-glucosecontrol-and-insulin-therapy, accessed 8 Jan 2014.

11. Canadian Diabetes Association Clinical Practice Guidelines Expert Committee (2013) Canadian Diabetes Association 2013. Clinical Practice Guidelines for the Prevention and Management of Diabetes in Canada. Can J Diabetes 37: S1-S212.

12. National Board of Health and Welfare (2010) Nationella Riktlinjer för diabetesvården. (National Guidelines for Diabetes Care) http:// www.socialstyrelsen.se/nationellariktlinjerfordiabetesvarden, accessed 10 May 2014.

13. Swedish National Diabetes Register, Annual Report 2012. Available at: https://www.ndr.nu/pdf/Annual_Report_NDR_2012.pdf, accessed 8 Jan 2014.
14. Carlsson BM, Attvall S, Clements M, Gumpeny SR, Pivodic A, et al. (2013) Insulin pump-long-term effects on glycemic control: an observational study at 10 diabetes clinics in Sweden. Diabetes TechnolTher 15: 302-307.

15. Anderson J, Attvall S, Sternemalm L, Pivodic A, Fahlén M, et al. (2011) Effect on glycemic control by short- and long-term use of continuous glucose monitoring in clinical practice. J Diabetes SciTechnol 5: 1472-1479.

16. Carlsson BM, Andersson PN, Alnervik J, Carstensen J, Lind M (2012) Availability of insulin pump therapy in clinical practice. Diabet Med 29: 1055-1059.

17. Lind M, Fahlén M, Happich M, Odén A, Eliasson B (2009) The effect of insulin lispro on glycemic control in a large patient cohort. Diabetes TechnolTher 11: 51-56.

18. Lind M, Odén A, Fahlén M, Eliasson B (2009) The true value of HbAlc as a predictor of diabetic complications: simulations of HbAlc variables. PLoS One 4: e4412.

19. (2006) Applied Mixed Models in Medicine (2nd edn). Helen Brown and Robin Prescott, Wiley.

20. Kostev K, Grunow S, Rockel T (2012) HbAlc testing frequency in primary care diabetes patients in Germany and in the UK. ISPOR 15th annual European congress research abstracts. Value in Health 15: A519.

21. National Institute of Clinical Studies (2008) Evidence-Practice Gaps Report Volume 1: A review of developments: 2004-2007. Measuring glycated haemoglobin in diabetes management. Canberra: National Health and Medical Research Council: 18-19.

22. Driskell OJ, Holland D, Hanna FW, Jones PW, Pemberton RJ, Tran M, Fryer AA (2012) Inappropriate requesting of glycated hemoglobin ( $\mathrm{HbAlc})$ is widespread: assessment of prevalence, impact of national guidance, and practice-to-practice variability. Clin Chem 58 (5): 906-915.

23. Hansen MV, Pedersen-Bjergaard U, Heller SR, Wallace TM, Rasmussen AK, et al. (2009) Frequency and motives of blood glucose self-monitoring in type 1 diabetes. Diabetes Res ClinPract 85: 183-188.

24. Miller KM, Beck RW, Bergenstal RM, Goland RS, Haller MJ, T1D Exchange Clinic Network (2013) Evidence of a strong association between frequency of selfmonitoring of blood glucose and hemoglobin Alc levels in T1D exchange clinic registry participants. Diabetes Care 36: 2009-2014.

25. Misso ML, Egberts KJ, Page M, O'Connor D, Shaw J (2010) Continuous subcutaneous insulin infusion (CSII) versus multiple insulin injections for type 1 diabetes mellitus. Cochrane Database Syst Rev : CD005103.

26. Singh SR, Ahmad F, Lal A, Yu C, Bai Z, et al. (2009) Efficacy and safety of insulin analogues for the management of diabetes mellitus: a meta-analysis. CMAJ 180: 385-397.

27. Plank J, Siebenhofer A, Berghold A, Jeitler K, Horvath K, et al. (2005) Systematic review and meta-analysis of short-acting insulin analogues in patients with diabetes mellitus. Arch Intern Med 165: 1337-1344. 